\title{
Husbands a drag to high-flying physicists
}

[LONDON] Many women physicists in the United States face special obstacles in their career progression because they are married to physicists or other scientists, according to a new study.

Nearly 45 per cent of married female physicists have physicist spouses, though only 6 per cent of male physicists are in the same position. This means that many female physicists looking for a job have a husband in the same field - where, typically, few jobs are available, say Laurie McNeil of the University of North Carolina and Marc Sher of the College of William and Mary in Virginia. They will present their findings to a meeting of the American Physical Society (APS) in Atlanta, Georgia, this week.

Compounding the problem, university departments tend to be unresponsive to dual-career issues, according to the study, which was undertaken for the APS's Committee on the Status of Women in Physics.

The authors say that the problems they have identified represent significant constraints on the growth of the small community of female physicists.

In a survey of 620 dual-career couples where one partner was a physicist, which McNeil and Sher made last year, 60 per cent said that one partner had taken a lower-level science job, a non-science job or no job at all owing to the difficulty they had in finding two scientific appointments at the same location.

Although some institutions have tried to find solutions to the problem — such as creating split or shared positions or spousehiring programmes - most respondents said that, in their experience, institutions tend either to handle dual-career issues badly or to ignore them altogether.

Members of couples who were both pursuing careers in science said they had been given less consideration for a post, or none at all, when it became clear they were part of such a couple. Rules against nepotism are often, incorrectly, cited as a reason why an institution is unable to help spouses find employment there.

"There are ways to address these problems - and it's very important for institutions to address them, as they won't go away," says McNeil.

Judy Franz, the executive officer of APS, says: "Universities rarely deal with issues until they have to. In physics, until recently, the majority of departments had no women faculty and therefore never had to deal with this challenge."

The report points out that many institutions view dual-career couples as an administrative problem, rather than an opportunity, and are unable to see the benefits that dual-career couples can bring. McNeil and Sher say that institutions

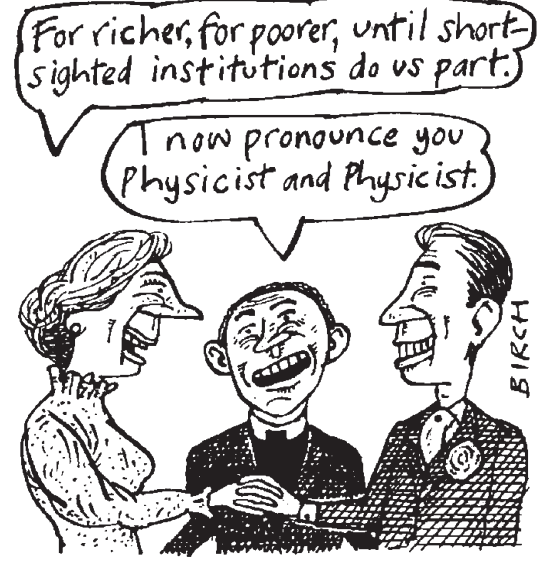

offering options for dual-career couples will, in fact, attract the best staff and will stand a better chance of retaining them.

The University of Illinois, for example, has established a dual-career couple programme, which focuses on improving recruitment and retention of faculty members when the appointment or retention of one partner is contingent upon the employment of another.

Franz was taken aback by the lack of progress that the survey reveals, especially because some institutions have had policies in place since the 1970s.

"I was most surprised by the negative attitudes expressed," she says. "I thought that they had mostly gone by now."

One potential employer told a candidate that his partner "shouldn't be working anyway". Another candidate was told that his wife should make herself available to do voluntary scientific work, since it was his role to support the family.

"A lot of remarks and responses sounded like something of an earlier era," says McNeil. "You wouldn't think people behaved in that way, although you might have expected it 20 years ago."

With greater numbers of women entering physics, institutions hiring physicists are increasingly likely to find that their best candidate has a spouse seeking professional employment. Institutions have a role to play if the number of female physicists is to increase, $\mathrm{McNeil}$ and Sher say. "It is within the power of the institutions to help ease the situation or to make it worse," their report says.

The full 60-page report, with relevant links, is available at: http://www.physics.wm. edu/dualcareer.html

NatashaLoder

\section{California approves $\$ 1.5$ billion campus}

[SAN DIEGO] The University of California at San Francisco (UCSF) has begun developing a new life-sciences research campus at a cost of up to $\$ 1.5$ billion.

The University of California Board of Regents last week approved the first building of the new Mission Bay campus. The \$222 million complex will house centres for structural and chemical biology and for molecular and cell biology.

Plans for a second building, with laboratories for genetics, developmental biology and neurobiology, at a cost of about $\$ 100$ million, are near completion. These plans are expected to be approved soon.

The Mission Bay campus is designed to replace much of the present UCSF research facilities adjacent to its medical centre at the Parnassus Heights campus, where buildings have been damaged by earthquakes, laboratory space is at a premium, and expansion is limited by residents' objections.

The 43-acre Mission Bay campus, to be built on the site of a former railway yard and warehouse district in the south-eastern part of the city, will be ringed by private development of biotechnology and related firms that hope to capitalize on the new research complex.

The project is being compared by its supporters to the Stanford Industrial Park, which formed the nucleus of Silicon Valley near Stanford University.

"This represents a dramatic opportunity for our campus," said Zach Hall, a neuroscientist who is UCSF's vicechancellor for research. "Most of our existing basic research faculty will move to the new campus and there will be a significant number of new faculty and associates in the future."

Hall could not specify how many new research positions will be created, but said that as lab space grows, so too will staff and educational opportunities. The first building will have laboratories for about 50 principal investigators and will eventually house 900 personnel. When completed, the Mission Bay campus will provide work space for about 9,000 scientists, graduate students and staff in 20 buildings.

Current plans call for focusing on basic research at the Mission Bay campus, with disease-related research efforts remaining at the Parnassus Heights campus near the UCSF medical centre.

The cost of the first building on the Mission Bay campus is being met by $\$ 110$ million in gifts, $\$ 70$ million in bonds, $\$ 21$ million in state funds, and $\mathbf{\$ 1 8}$ million in lease payments from the Howard Hughes Medical Institute, which will occupy part of the building.

Rex Dalton 